Research Paper

ADVANCE RESEARCH JOURNAL OF

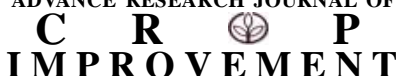

Volume $\mathbf{9}$ | Issue 1 | June, 2018 | 5-7

•.... e ISSN-2231-640X

DOI :

10.15740/HAS/ARJCI/9.1/5-7

Visit us: www.researchjournal.co.in

Author for correspondence: Chandra Kumar Singh Krishi Vigyan Kendra, Tawang, Changbu (Arunachal Pradesh) India

Email: chandrasinghagronomy @gmail.com

\section{Effect of organic mannure on yield attributes and seed yield of soybean in Tawang district of Arunachal Pradesh}

\author{
Chandra Kumar Singh
}

\begin{abstract}
A field experiment was conducted during the Kharif season of 2016 and 2017 at three village's viz., Sernup, Poito and Namtsering in Tawang district of Arunachal Pradesh to study the effect of organic manures on yield attributes and seed yield of soybean (Glycine max L.). The experiment, consisted of four treatment of organic manures viz., control, farmyard manure (F.Y.M) @ 6.0 t/ha, vermicompost @ 3.0 t/ha and F.Y.M @ 3.0t/h + vermicompost @ 1.0t/ ha resulted in significantly the highest seed ( 23.39 q/ha.) as compared to application of F.Y.M. @ $6.0 \mathrm{t} / \mathrm{ha}$, vermicompost @ $2.0 \mathrm{t} / \mathrm{ha}$. and control. Significantly the highest number of pods/ plant and grain/pod were recorded with the application of F.Y.M @3.0 t/ha.+ vermicompost @ 1.0 t/ha.as compared to sole application of F.Y.M @ 6.0 t/ha. vermicompost @ 2.0 t/ha. and control.
\end{abstract}

KEY WORDS : Soybean, Farmyard manure, Vermicompost, Seed yield, Economics

How to cite this paper : Singh, Chandra Kumar (2018). Effect of organic mannure on yield attributes and seed yield of soybean in Tawang district of Arunachal Pradesh. Adv. Res. J. Crop Improv., 9 (1) : 5-7, DOI : 10.15740/HAS/ARJCI/9.1/5-7.

Paper History : Received : 06.02.2018; Revised : 18.05.2018; Accepted : 24.05.2018 